\title{
A report on the mass summer mortalities of the farmed Pacific oysters, Crassostrea gigas and Bay scallops Argopecten irradians in the local waters of Goseong Bay, Korea
}

\author{
Jong Cheol Han, Qtae Jo, Young Cheol Park, Tae Gyu Park, Deok Chan Lee and \\ Kee-Chae Cho
}

Southeast Sea Fisheries Research Institute, NFRDI, Tongyeong, Kyeognam 650-943, Korea

\begin{abstract}
Mass mortalities of farmed shellfish, mostly in summer season, thus named mass summer mortalities, have been a global issue in shellfish aquaculture. The 2013 mass summer mortalities in the confined waters of Goseong Bay, Goseong, Korea were quite a unique and intensive for two farmed species, the Pacific oysters, Crassostrea gigas, and bay scallops, Argopecten irradians. The mortalities were progressive from the bottom of the suspended oysters and caged scallops in the waters, reaching up to $80 \%$ for the oyster and $95 \%$ for the scallop in about 20 days after the first occurrence, early August, 2013. We monitored a wide range of environmental factors, including water temperature, dissolved oxygen (DO), salinity, turbidity, acidity $(\mathrm{pH})$, organic and inorganic matters, chemical oxygen demand (COD), suspected pathogenic agent, and phytoplankton composition throughout the water column where the two species were suspended or caged. Our survey concluded that the hypoxia or anoxia might be a major cause of the mortalities. Here, we detailed the mortalities and ways to arrive at the conclusion.
\end{abstract}

Key words: Mass summer mortality, Hypoxia, Crassostrea gigas, Argopecten irradians.

\section{Introduction}

Goseong Bay, Goseong, Korea provides a relatively small but productive water body for oysters and scallops. In August, 2013, farmed oysters Crassostrea gigas and scallops Argopecten irradians experienced great mortalities in the local waters of the bay. The mortalities occurred over a short period of time and they were significant and quite an abnormal.

Mass summer mortalities of shellfish have been a global happening over a variety of shellfish, including oysters (Cheney et al., 2000; Pernet et al., 2012) and scallops (Gulka et al., 1983; NFRDI, 2005; Xiao et al.,

Received: September 13, 2013; Accepted: September 27, 2013

Corresponding author : Qtae Jo

Tel: +82 (55) 640-4731 e-mail: qtjo@korea.kr

$1225-3480 / 24492$ Access article distributed under the terms of the Creative Commons Attribution Non-Commercial License with permits unrestricted non-commercial use, distribution, and reproducibility in any medium, provided the original work is properly cited.
2005). A sheer number of studies on the subject have fully unveiled the primary causes for the mortalities: temperature extremes beyond the acclimatization capacities (Gagnaire et al., 2006a), pathogenic agents (Chu and La Peyre, 1993), hypoxia or anoxia (Vaquer-Sunyer and Duarte, 2008), reduction in heterozygosity (Watt and Dean, 2000), overall pollutants (Gagnaire et al., 2006b), malnutrition (Thompson and Harrison, 1992), bad management (Kaiser et al., 1998), recent climate change, and so on (Zillen et al., 2008). The underling working mechanism for each cause for the mortality is well documented. But, the mortalities in reality are expected to be much more complicated. The damages, for example, can be exacerbating when more than two causes are co-working (Vaquer-Sunyer and Duarte, 2010; Ivanina et al., 2012).

In the cellular consequences of the hypoxia, deficient oxygen elicits the transition to passive tolerance and associated systemic and cellular stress signals like hormonal responses or oxidative stress as well as 


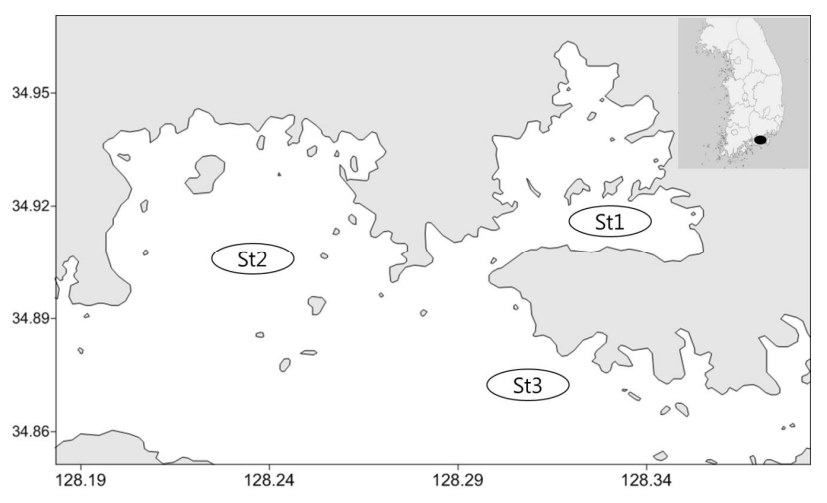

Fig. 1. Location of Goseong Bay, Korea (black spot on the peninsula), showing the study stations: St-1 for oyster farms, St-2 for scallop farms, and St-3 for farms for both species.
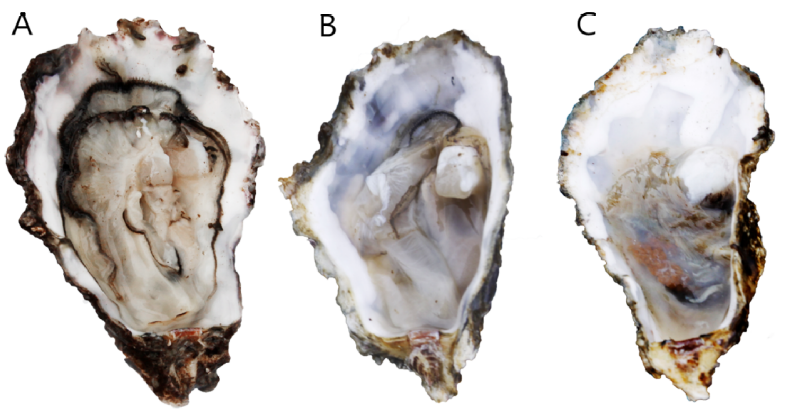

Fig. 2. Representative internal views of Crassostrea gigas, normal (A), alive but going to mortality (B), and dead (C).

expression of molecular chaprones and others at thermal extremes (Portner, 2010; Han et al., 2013). Therefore, hypoxia drives it in the kernel of discussion in the physiology of mass summer mortality because the likelihood that deficiency of oxygen can exacerbate the damage is high. In this regard, we monitored the 2013 summer mortalities of oysters and scallops in terms of the animal mortalities and their ambient water qualities that can be potential causes for the mortalities with a special focus on hypoxia together with temperature.

\section{Materials and Methods}

\section{Study area}

Three study sites named stations $1-3$ were places in the highly sheltered and relatively small bay, Goseong Bay, Goseong, Korea where both of oysters suspended and scallops lantern-caged exhibited significant mortalities (Fig. 1). Each station differed by the species farmed: station 1 (St-1) for oysters, station 2 (St-2) for scallops, and station 3 (St-3) for both.

\section{Mortality count}

Mortalities of the oysters and scallops were directly counted on the research vessel. Individuals demonstrating an apparent tendency or on the verge of mortality by appearance were considered as a mortality count (Fig. 2).

\section{Environmental measurement}

Temperature, dissolved oxygen (DO), acidity $(\mathrm{pH})$, and salinity were directly determined from bottom to surface waters on every meter basis with an aid of a water quality monitoring instrument (YSI-6000, YSI, USA). For the measurements of chemical oxygen demand (COD) and nitrogenous compounds such as $\mathrm{NH}_{4}-\mathrm{N}, \mathrm{NO}_{2}-\mathrm{N}$, and $\mathrm{NO}_{3}-\mathrm{N}$, surface and bottom waters were sampled using a water sampler (Niskin water sampler-1010, General Oceanics, USA) and immediately bottled and transferred into the laboratory for the analyses. Water transparency was measured by measuring Secchi depth. All the analytical details, otherwise mentioned, followed Standard Methods for the Examination of Environment Pollution (2010).

\section{Pathological monitoring}

Five samples from each species representing animal status normal and tendency of mortality for oysters and live for scallops were kept alive prior to laboratory analysis. Analyzed were the adduct muscles and heart tissues for bacterial agents and gill and heart tissues for parasites under microscope (Carlzeiss, IMAGE A2, Germany). For the analysis of Perkinsus olseni, DNA samples of mantle and adductor muscles were analyzed in PCR (Biorad 170-8710, USA) with an aid of PolsITS primer (5'-GAC CGC CTT AAC GGG CCG TGT T-3') and PolsITS-600R primer (5'GGR CTT AGC ATC CAA AG-3') (Lee et al., 2010).

\section{Phytoplankton composition}

Waters of study area were collected (1L) using water 
sampler. The collected samples were moderately concentrated and then analyzed for phytoplankton identification under a light microscope.

\section{Results and Discussion}

\section{Mortalities}

Table 1 summarizes aquaculture and mortalities of the two species in study. The ways of aquaculture for the two species were normal except for way for scallop in which lantern cage deployment or suspension interval was relatively narrow. The lantern cage suspension intervals of our study site were $40-50 \mathrm{~cm}$, about half a normal interval for other scallops (Parsons, 1992). This, however, is more related to growth performance than to mortality (Zhang et al., 1991; Parsons, 1992). The mortalities initiated from early August ranged $80-95 \%$ for oyster and $50-98 \%$ for scallop in two to 3 weeks. They were exceptional, compared with those observed from our routine mortality monitoring, at most $10-20 \%$ (data, not shown). Interestingly, there was a narrow vertical range carrying 2-3 collectors in the suspended culture line. The most of the oysters in the collectors were characterized by two types: dead or alive but lacking viability. The oysters upper the range were normal or alive but lacking viability. Strikingly, total or almost total mortalities were found down the range, reminiscent of a sign explaining the progressive mortalities "upward".

\section{Water qualities}

Water qualities representing study stations were graded on Table 2. The waters of the study stations were highly turbid by appearance (less than $2 \mathrm{~m}$ in Secchi disk). However, the measurements exhibited standard level or slightly lowered the standard, except for the measurements of COD (see Korean Standard Methods for the Examination of Environment Pollution, 1998).

\section{Phytoplankton composition}

All the stations were dominated by protozoan flagellate sized smaller than $1 \mu \mathrm{m}$ followed by diatom Chaetoceros spp. For example, total cell counts for St-1 were $20,025 \mathrm{cell} / \mathrm{ml}$ for flagellates and $12,475 \mathrm{cell} / \mathrm{ml}$ for diatoms. The trends were similar for the waters of ST-2 and St-3. A flagellate Akashiwo sanguineum remained as a minor composition, 5-20 cell $/ \mathrm{ml}$. A few of Ceratium fusus and Dinophysis sp. were also noticed in our phytoplankton survey. However, none of

Table 1. Aquaculture operation and mortality for the two species Crassostrea gigas and Argopecten irradians in the survey

\begin{tabular}{|c|c|c|c|c|c|c|}
\hline $\begin{array}{l}\text { Species } \\
\text { cultured }\end{array}$ & Culture type & $\begin{array}{l}\text { Suspension } \\
\text { length }(\mathrm{m})\end{array}$ & $\begin{array}{l}\text { Suspension* } \\
\text { interval }(\mathrm{cm})\end{array}$ & $\begin{array}{l}\text { Culture }{ }^{* *} \\
\text { density }\end{array}$ & $\begin{array}{c}\text { Shell length } \\
\text { size }(\mathrm{cm})\end{array}$ & Mortality (\%) \\
\hline Scallop & Lantern cage & $5-6$ & $40-60$ & $15-50$ & $2.5-6.0$ & $50-100$ \\
\hline Oyster & Longline & $5-8$ & $40-50$ & $5-8$ & $8-10$ & $80-95$ \\
\hline
\end{tabular}

*Interval of vertical suspension on the longline.

**Ind./collector for C. gigas and ind./layer for A. irradians.

Table 2. Water quality measurement for the study stations

\begin{tabular}{ccccccccc}
\hline \multicolumn{2}{c}{ Location } & $\begin{array}{c}\mathrm{COD} \\
\mathrm{mg} \mathrm{L}\end{array}$ & $\begin{array}{c}\mathrm{NH}_{4}^{-\mathrm{N}} \\
\mathrm{mg} / \mathrm{L}\end{array}$ & $\begin{array}{c}\mathrm{NO}_{2}-\mathrm{N} \\
\mathrm{mg} / \mathrm{L}\end{array}$ & $\begin{array}{c}\mathrm{NO}_{3}-\mathrm{N} \\
\mathrm{mg} / \mathrm{L}\end{array}$ & $\begin{array}{c}\mathrm{DIN} \\
\mathrm{Mg} / \mathrm{L}\end{array}$ & $\begin{array}{c}\mathrm{PO}_{4}-\mathrm{P} \\
\mathrm{Mg} / \mathrm{L}\end{array}$ & $\begin{array}{c}\mathrm{Chl}-\mathrm{a} \\
\mu \mathrm{g} / \mathrm{L}\end{array}$ \\
\hline \multirow{2}{*}{$\mathrm{St}-1$} & $\mathrm{SW}$ & $3.22 \pm 0.017$ & $0.019 \pm 0.001$ & $0.001 \pm 0.0007$ & $0.010 \pm 0.0002$ & $0.031 \pm 0.0002$ & $0.003 \pm 0.0002$ & $6.6 \pm 1.2$ \\
& $\mathrm{BW}$ & $2.49 \pm 0.125$ & $0.029 \pm 0.002$ & $0.003 \pm 0.0012$ & $0.012 \pm 0.0002$ & $0.045 \pm 0.0002$ & $0.015 \pm 0.0002$ & \\
\hline \multirow{2}{*}{$\mathrm{St}-2$} & $\mathrm{SW}$ & $2.20 \pm 0.047$ & $0.011 \pm 0.002$ & $0.003 \pm 0.0008$ & $0.018 \pm 0.0002$ & $0.032 \pm 0.0002$ & $0.004 \pm 0.0002$ & $2.8 \pm 0.5$ \\
& $\mathrm{BW}$ & $2.34 \pm 0.255$ & $0.016 \pm 0.003$ & $0.004 \pm 0.0013$ & $0.020 \pm 0.0002$ & $0.041 \pm 0.0002$ & $0.014 \pm 0.0002$ \\
\hline \multirow{2}{*}{ St-3 } & $\mathrm{SW}$ & $2.69 \pm 0.851$ & $0.007 \pm 0.001$ & $0.002 \pm 0.0004$ & $0.012 \pm 0.0002$ & $0.021 \pm 0.0002$ & $0.003 \pm 0.0002$ & $4.2 \pm 1.5$ \\
& $\mathrm{BW}$ & $0.14 \pm 0.002$ & $0.002 \pm 0.000$ & $0.004 \pm 0.0022$ & $0.005 \pm 0.0002$ & $0.006 \pm 0.0002$ & $0.007 \pm 0.0002$ & \\
\hline
\end{tabular}

Location abbreviations: BW, bottom water; SW, surface water. 
Mass summer mortality of shellfish

Table 3. Depth dependent DO (ppm) and mortality (\%) of C. gigas and/or A. irradians at the study stations

\begin{tabular}{ccccccc}
\hline \multirow{2}{*}{ Location } & \multicolumn{9}{c}{ Depth $(\mathrm{m})$} \\
\cline { 2 - 7 } & 1 & 2 & 3 & 4 & 5 & 6 \\
\hline \multirow{2}{*}{ St-1 } & $6.71 \pm 0.45$ & $6.17 \pm 0.25$ & $4.49 \pm 1.11$ & $2.61 \pm 0.15$ & $1.65 \pm 0.08$ & $1.47 \pm 0.08$ \\
& $(23.3 \pm 7.7)^{*}$ & $(81.7 \pm 10.4)$ & $(95.33 \pm 3.1)$ & $(99.7 \pm 0.6)$ & $(100 \pm 0.0)$ & $(100 \pm 0.0)$ \\
\multirow{2}{*}{ St-2 } & $6.65 \pm 0.06$ & $6.25 \pm 0.21$ & $6.06 \pm 0.05$ & $2.38 \pm 0.35$ & $1.85 \pm 0.12$ & $1.55 \pm 0.01$ \\
& $(51.8 \pm 8.6)$ & $(69.0 \pm 9.4)$ & $89.7 \pm 4.1$ & $96.6 \pm 5.8$ & $(100 \pm 0.0)$ & $(100 \pm 0.0)$ \\
\multirow{2}{*}{ St-3 } & $6.87 \pm 0.28$ & $6.47 \pm 0.06$ & $5.15 \pm 0.54$ & $4.6 \pm 0.52$ & $4.0 \pm 0.32$ & $3.87 \pm 0.39$ \\
& $(37.5 \pm 10.0)$ & $(75.3 \pm 5.8)$ & $92.5 \pm 1.0$ & $98.2 \pm 0.6$ & $(100 \pm 0.0)$ & $(100 \pm 0.0)$ \\
\hline
\end{tabular}

*Figure in parenthesis implies mortalities: St-1 for C. gigas; St-2 for A. irradians; St-3 for both species on average.

Cochlodinium spp. was observed. The diatom outgrowth, together with minor appearance of $A$. sanguineum, appeared to be responsible for the turbidity and a sign for a succession in species composition in the study area.

\section{Causes of mortalities}

There are many causes for shellfish mass summer mortalities. Of them, temperature and dissolved oxygen are worth paying attention because of their bigger damage potentials. Pathogenic agents are also responsible for many mass summer mortalities (Xiao et al., 2005; Thieltges, 2006; Garnier et al., 2007), but they as an opportunistic invader (Lacoste et al., 2001) may remain as a secondary cause.

We monitored a variety of potential causes for the mortalities, including temperature, pathogenic agents, hypoxia or anoxia, salinity, acidity, and overall pollutants. The measurements except for temperature, salinity, and pathogenic agents were absolutely or to some extent unfavorable. Even though the measurements were unfavorable for normal shellfish life, the levels were still within the magnitudes the animal could resist.

One of the most distinctive and conspicuous observations was dissolved oxygen. Fig. 3 detailed the profiles of dissolved oxygen and temperature. Dissolved oxygen levels in the surface waters were overall low. But there was a great fall in dissolved oxygen level with water depth. It was far below the normal level or in hypoxia from depth 4 meter. Compared with each of environment measurements, the mortalities were most closely related with the change of dissolved oxygen (Table 3). This indicates the hypoxia as a key culprit of the shellfish mortalities. The finding that depth of a narrow vertical range in the suspended culture line containing the shellfish dead and alive but lacking viability further support our conclusion.

In the study of hypoxic waters that impact ecosystem, thresholds for hypoxia in coastal ecosystems are higher than previously thought and are not static, but regulated by local and global processes, being particularly sensitive to warming (Steckbauer et al., 2011). The oxygen level, 2ppm, used to be a threshold level for hypoxia (Diaz and Rosenberg, 1995) was argued by many experimental evidences that experienced onsets of hypoxic mortalities at higher concentrations (Gray et al., 2002; Vaquer-Sunyer and Duarte, 2008; Steckbauer et al., 2011). In this regard, the two species placed in the waters 3-4 meters deep appeared to face the hypoxia, resulting in mass mortalities.

The frequency of hypoxic events is increasing due to global eutrophication (Vaquer-Sunyer and Duarte, 2008; Rabalais et al., 2009). This increase in frequency

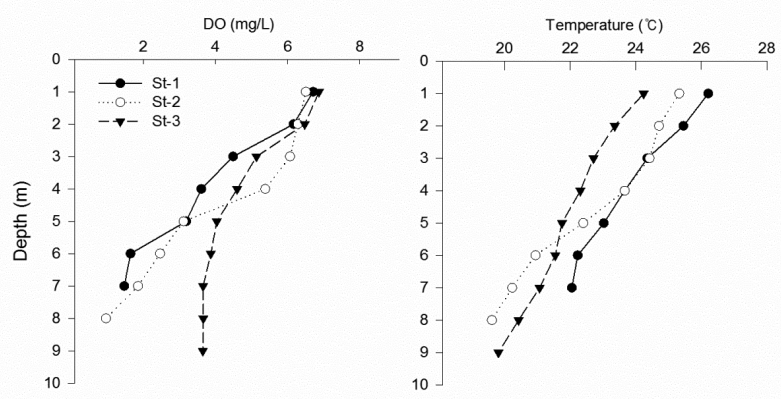

Fig. 3. Vertical profiles of dissolved oxygen (DO) and temperature at three study stations. 
is emerging as a common stressor in coastal ecosystem (Vaquer-Sunyer and Duarte, 2008). In general in a given location, hypoxia occurs when respiration by the resident biota, especially photosynthetic microorganisms, outstrips the oxygen input into the water from photosynthesis, diffusion from the nearby oxygenated areas, and atmospheric exchange (Diaz and Rosenberg, 2008; Vaquer-Sunyer and Duarte, 2008; Tilman et al., 2001; Ivanina et al., 2012). The hypoxia observed in the present study was prominent in the near-bottom water layers, with a gradient increasing upward. Thus, anaerobic metabolism from the near-bottom appeared to be one of the triggers of the hypoxia.

This might be particularly plausible in a highly sheltered and nutritious water body as a spatial extent of hypoxia is highly sensitive to small changes in the bigger water body, with maximum responses at suboxic concentrations where anaerobic metabolisms predominate (Deutsche et al., 2011). Even though we could not define the origin of the extremely low dissolved oxygen in the study area, its persistence appeared to be related with the size and geographical structure of the bay. Once generated, the hypoxia appeared to persist due to the highly sheltered structure of the bay, damaging the farmed shellfish.

\section{Acknowledgements}

This work was financially supported by NFRDI Research Funds for Technology Development of Individual Oyster Aquaculture in the Floating Cage. Parts of data were from Goseong County, Gyeongnam Provinve, Korea.

\section{REFERENCES}

Cheney, D.P., MacDonald, B.F. and Elston, R.A. (2000) Summer mortality of Pacific oysters, Crassostrea gigas (Thunberg): initial findings on multiple environmental stressors in Puget Sound, Washington, 1998. Journal of Shellfish Research, 19: 353- 359.

Christine, M.C. and Catriona, K.A. Macleod and Mitchell, I.M. (2003) Effects of shellfish farming on the benthic environment. Aquaculture, 224: 117-140.

Chu, F.L.E. and La Peyre, J.F. (1993) Perkinsus marinus susceptibility and defense-related activities in eastern oysters Crassostrea virginica: temperature effects.
Diseases of Aquatic Organisms, 16: 223-234.

Deutsch, C., Brix, H., Ito, T., Frenzel, H. and Thompson, L. (2011) Climate-forced variability of ocean hypoxia. Science, 333: 336-339.

Diaz, R.J. and Rosenberg, R. (1995) Marine benthic hypoxia: a review of its ecological effects and the behavioural responses of benthic macrofauna Oceanogr. Marine Biology Annual Review, 33: 245-303.

Diaz, R.J. and Rosenberg, R. (2008) Spreading dead zones and consequences for marine ecosystems. Science, 321: 926-929.

Gulka, G., Chang, P.W. and Marti, K.A. (1983) Prokaryotic infection associated with a mass mortality of the sea scallop, Placopecten magellanicus. Journal of Fish Diseases, 6: 355-364.

Han, G.D., Zhang, S., Marshall, D.J., Ke, C. and Dong, Y. (2013) Metabolic energy sensors (AMPK and SIRT1), protein carbonylation and cardiac failure as biomarkers of thermal stress in an intertidal limpet: linking energetic allocation with environmental temperature during aerial emersion. Journal of Experimental Biology, 216: 3273-3282.

Ivanina, A.V., Kurochkin, I.O., Leamy, L. and Sokolova, I.M. (2012) Effects of temperature and cadmium exposure on the mitochondria of oysters (Crassostrea virginica) exposed to hypoxia and subsequent reoxygenation. Journal of Experimental Biology, 215: 3142-3154.

Kaiser, M.J., Laing, I., Utting, S.D. and Burnell, G.M. (1998) Environmental impacts of bivalve mariculture. Journal of Shellfish Research, 17: 59-66.

Lacoste, S.A. (2001) Stress and Stress-Induced Neuroendocrine Changes Increase the Susceptibility of Juvenile Oysters (Crassostrea gigas) to Vibrio splendidus. Applied and Environmental Microbiology, 67: 2304-2309.

Moullac, L., Soyez, G.C., Saunier, D., Ansquer, D., Avarre, J.C. and Levy, P. (1998) Effect of hypoxic stress on the immune response and the resistance to vibriosis of the shrimp Penaeus stylirostris. Fish and Shellfish Immunology, 8: 621-629.

Gagnaire, B., Frouin, H., Moreau, K., Thomas-Guyon, H. and Renault T. (2006a) Effects of temperature and salinity on haemocyte activities of the Pacific oyster, Crassostrea gigas (Thunberg). Fish and Shellfish Immunology, 20: 536-547.

Gagnaire, B., Frouin, H., Moreau, K., Thomas-Guyon, H. and Renault, T. (2006b) Pollutant effects on Pacific oyster, Crassostrea gigas (Thunberg), hemocytes: Screening of 23 molecules using flow cytometry. Cell Biology and Toxicology, 22: 1-14.

Garnier, M., Labreuche, Y., Garcia, C., Robert, M. and Nicolas, N.L. (2007) Evidence for the Involvement of Pathogenic Bacteria in Summer Mortalities of the Pacific Oyster Crassostrea gigas Evidence for the Involvement of Pathogenic Bacteria in Summer Mortalities of the Pacific Oyster Crassostrea gigas. Microbial Ecology, 53: 187-196. 
Lee, N.S., Hwang, J.Y., Choi, D.L. and Park, M.A. (2010) Survey of Perkinsus olseni infection in Manila clam, Ruditapes philippinarum in 2009 on the west and south coast of Korea using PCR technique. Journal of Fish Pathology, 23: 145-153.

McBryan, T.L., Anttila, T.L., Healy T.M. and Schulte, P.M. (2013) Responses to Temperature and Hypoxia as Interacting Stressors in Fish: Implications for Adaptation to Environmental Change. Integrative and Comparative Biology, 53: 648-659.

Myrand B. and Gaudreault, J. (1995) Summer mortality of blue mussel (Mytilus edulis Linneaus, 1758) in the Magdalen islands (southern gulf of St. Lawrence, Canada). Journal of Shellfish Research, 14: 395-404.

Parsons, G.J. and Dadswell, M.J. (1992) Effect of stocking density on growth, production, and survival of the giant scallop, Placopecten magellanicus, held in intermediate suspension culture in Passamaquoddy Bay, New Brunswick. Aquaculture, 103: 291-309.

Pernet, F., Barret, J., Le Gall, P., Corporeau, C., Degremont, L., Lagarde, F., Pepin, J.F. and Keck, N. (2012) Mass mortalities of Pacific oysters Crassostrea gigas reflect infectious diseases and vary with farming practices in the Mediterranean Thau lagoon, France. Aquaculture Environment Interaction, 2: 215-237.

Portner, HO. (2010) Oxygen- and capacity-limitation of thermal tolerance: a matrix for integrating climate-related stressor effects in marine ecosystems. Journal of Experimental Biology, 213: 881-893.

Rabalais, N.N., Turner, R.E., Diaz, R.J. and Justic, D. (2009) Global change and eutrophication of coastal waters. ICES Journal of Science Marine Science, 66: 1528-1537.

Standard Methods for the Examination of Environment Pollution. (2010) Ministry of Land, Transport and Maritime Affairs, Korea.

Steckbauer, A.C., Duarte, M., Carstensen, J., Vaquer-Sunyer, R. and Conley, D.J. (2011) Ecosystem impacts of hypoxia: thresholds of hypoxia and pathways to recovery. Environmental Research Letters, 6: 1-12.

Thieltges, D.W. (2006) Parasite Induced Summer Mortality in the Cockle Cerastoderma edule by the Trematode Gymnophallus choledochus. Hydrobiologia, 559: $455-461$.

Thompson, P.A. and Harrison, P.J. (1992) Effects of monospecific algal diets of varying biochemical composition on the growth and survival of Pacific oyster (Crassostrea gigas) larvae. Marine Biology, 113: 645-654.

Tilman, D., Fargione, J., Wolff, B., D'Antonio, C., Dobson, A., Howarth, R., Schindler, D., Schlesinger, W.H., Simberloff, D. and Swackhamer, D. (2001) Forecasting agriculturally driven global environmental change. Science, 292: 281-284.

Vaquer-Sunyer, R. and Duarte, C.M. (2010) Sulfide exposure accelerates hypoxia-driven mortality. Limnology Oceanography, 55: 1075-1082.

Vaquer-Sunyer, R. and Duarte, C.M. (2008) Thresholds of hypoxia for marine biodiversity. Proceedings of National Academy of Sciences, USA, 105: 15452-15457.

Watt, W.B. and Dean, A.M. (2000) Molecular-functional studies of adaptive genetic variation in prokaryotes and eukaryotes. Annual Review, 34: 593-622.

Xiao, J., Ford, S.E., Yang, H., Zhang, G., Zhang, F. and Guo., X. (2005) Studies on mass summer mortality of cultured zhikong scallops (Chlamys farreri Jones et Preston) in China. Aquaculture, 250: 602-615.

Zillen, L., Conley, D.J., Andren, T., Andren, E. and Bjorck, S. (2008) Past occurrences of hypoxia in the Baltic Sea and the role of climate variability, environmental change and human impact. Earth-Science Reviews, 91: 77-92.

Zhang, Fl., He, Y., Liu, X., Ma J., Li, S. and Qi, L. (1991) Introduction, spat-rearing and experimental culture of bay scallop, Argopecten irradians lamarck. Chinese Journal of Oceanography and Limnology, 9: 123-131. 